\title{
The advertisement call and comments on the distribution of Eleutherodactylus bilineatus Bokermann, 1975, an endemic frog of Bahia State, Brazil (Amphibia, Anura)
}

Iuri Ribeiro Dias ${ }^{1,2}$, Caio Vinicius de Mira-Mendes ${ }^{1,3}$, Carlos Augusto Souza-Costa', Flora Acuña Juncá ${ }^{4}$ Mirco Solé1,2

I Departamento de Ciências Biológicas, Universidade Estadual de Santa Cruz, Rodovia Jorge Amado, km 16, 45662-900 Ilhéus, Bahia, Brazil 2 Programa de Pós-Graduação em Zoologia, Universidade Estadual de Santa Cruz, Rodovia Jorge Amado, km 16, 45662-900 Ilhéus, Bahia, Brazil 3 Programa de Pós-Graduação em Sistemas Aquáticos Tropicais, Universidade Estadual de Santa Cruz, Rodovia Jorge Amado, km 16, 45662900 Ilhéus, Bahia, Brazil 4 Departamento de Ciências Biológicas, Universidade Estadual de Feira de Santana, Avenida Transnordestina, CEP44036-900, Feira de Santana, Bahia, Brazil

Corresponding author: Iuri Ribeiro Dias (iurirdias@hotmail.com)

Academic editor: A. Crottini | Received 17 February 2017 | Accepted 12 April 2017 | Published 30 May 2017

http://zoobank.org/3ACFA5AD-751E-4282-A13E-C36920C132EB

Citation: Dias IR, Mira-Mendes CV, Souza-Costa CA, Juncá FA, Solé M (2017) The advertisement call and comments on the distribution of Eleutherodactylus bilineatus Bokermann, 1975, an endemic frog of Bahia State, Brazil (Amphibia, Anura). ZooKeys 677: 151-159. https://doi.org/10.3897/zookeys.677.12309

\begin{abstract}
Advertisement calls can be used to aid solving taxonomic problems and understanding the evolution of certain groups. In this study, the advertisement call of Eleutherodactylus bilineatus is described. It is composed by two different notes with a total duration of 0.529-4.241 seconds and dominant frequency of $1.72-3.45 \mathrm{kHz}$. Additionally, new data is provided on the geographical distribution of Eleutherodactylus bilineatus and the most inland record for this species.
\end{abstract}

\section{Keywords}

Atlantic Forest, bioacoustics, vocalization, Holoadeninae, range extension

Copyright luri Ribeiro Dias et al. This is an open access article distributed under the terms of the Creative Commons Attribution License (CC BY 4.0), which permits unrestricted use, distribution, and reproduction in any medium, provided the original author and source are credited. 


\section{Introduction}

A recent research on the phylogenetic relationships within the anuran clade Terrarana, from the Brazilian Atlantic rainforest frog genus Ischnocnema, included Eleutherodactylus bilineatus as incertae sedis, likely close to the genus Noblella and Barycholos within the Holoadeninae (Canedo and Haddad 2012). Specimens of this species are small in size (snout-vent length of $20 \mathrm{~mm}$ in males and $26 \mathrm{~mm}$ in females) and inhabit the leaf litter of moist forests from the southern and central parts of Bahia, northeastern Brazil (Bokermann 1975, Frost 2016). It can be found up to $800 \mathrm{~m}$ above sea level and is occasionally encountered in cocoa plantations (Dias et al. 2014a,b, Juncá and Pimenta 2004).

Eleutherodactylus bilineatus (Figure 1) has a dark brown dorsal surface with two clear longitudinal stripes on each side of the body which inspire its popular name "Two-lined Robber Frog" (Bokermann 1975). It is not easily detected, and although their reproduction is presumably by direct development (Juncá and Pimenta 2004), there is limited information about its ecology and natural history. Here the advertisement call from two populations of Eleutherodactylus bilineatus is described and an updated map of the geographical distribution of this species provided, including new occurrence points.

\section{Materials and methods}

During the execution of the Project "Diversity and genetic structure of the amphibians of the Central Corridor of the Atlantic Forest of southern Bahia" supported by the Boticário Group Foundation for Nature Protection (Project n ${ }^{\circ} .0991 \_20132$ ), field expeditions were conducted lasting 7-8 days, using the same methodology and similar sampling efforts to nine different locations (Serra da Jibóia, Serra do Timbó, Wenceslau Guimarães, Serra do Corcovado, Pedra Lascada, Serra Bonita, Serra das Lontras, Macarani and PARNA Alto do Cariri), in the Atlantic Forest of Bahia. Specimens deposited in the Museum of Zoology of Universidade Estadual de Santa Cruz were also examined (Table 1), looking for new reports on the distribution of Eleutherodactylus bilineatus.

The advertisement call of Eleutherodactylus bilineatus was recorded at two sites in Bahia state: Serra da Jibóia, Santa Terezinha municipality (-12.728397; -39.569476, $790 \mathrm{~m}$ a.s.l.) and RPPN (Private Natural Heritage Reserve) Mata do Passarinho, Macarani municipality $(-15.79071 ;-40.51927,850 \mathrm{~m}$ a.s.l.). In the Serra da Jibóia the recordings were made on three different occasions: December 04, 1995, total of 10 calls from two males (air temperature $=21^{\circ} \mathrm{C}, 19: 40 \mathrm{~h}$ ); April 21, 1997, four calls from one male (air temperature $20^{\circ} \mathrm{C}, 20: 50 \mathrm{~h}$ ); and March 03, 2015, total of 36 calls from three males (air temperature $\left.21.4^{\circ} \mathrm{C}, 18: 15 \mathrm{~h}\right)$. The advertisement call $(\mathrm{n}=4)$ of one male from RPPN Mata do Passarinho (encountered in November 27, 2014) is also included in our analysis, recorded after it was placed in a plastic bag. These calls showed the same acoustic patterns as the calls from the males recorded in their natural environment. 


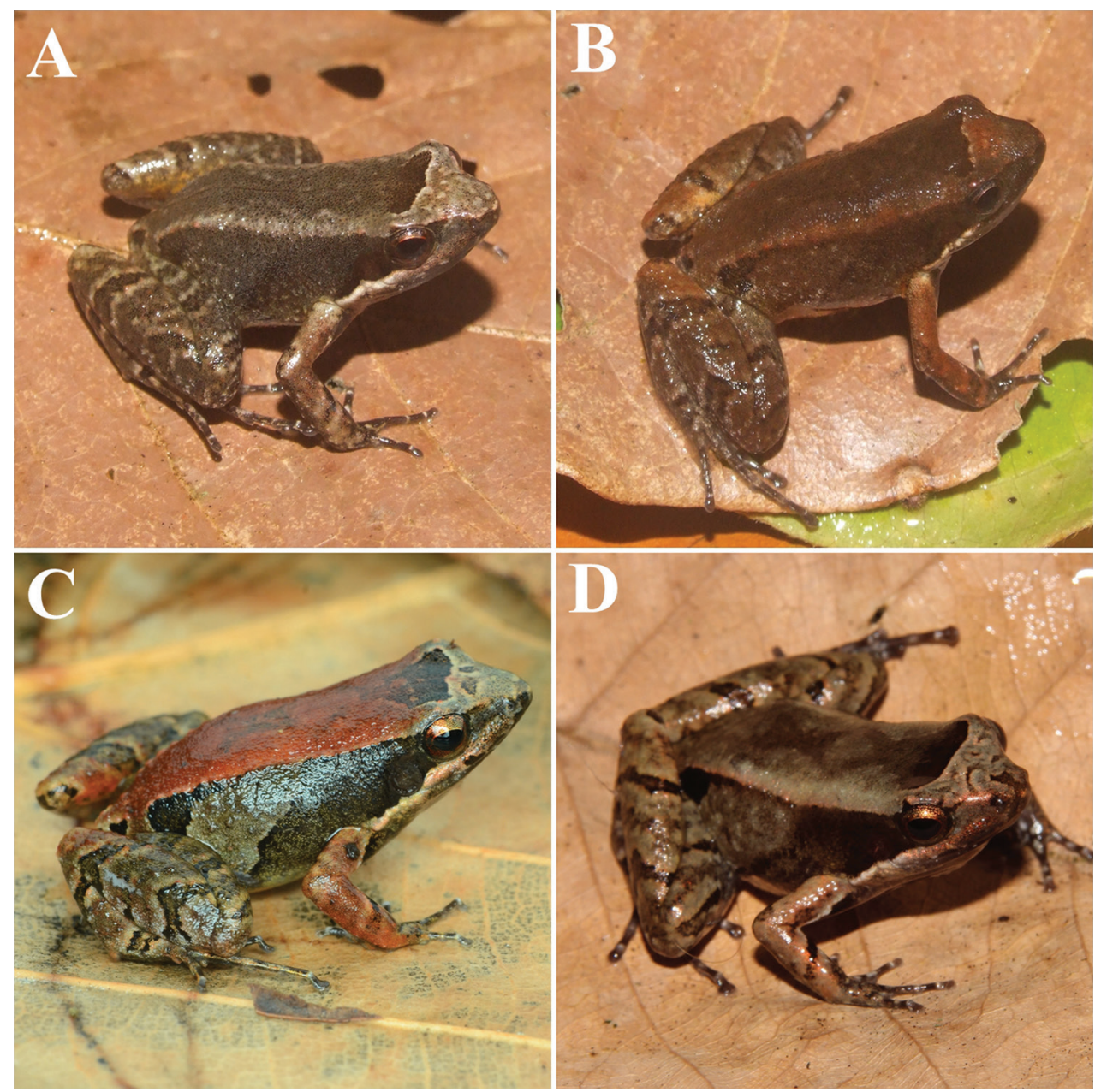

Figure I. Different individuals of Eleutherodactylus bilineatus showing some variation of the dorsal pattern of the species. A and B RPPN Mata do Passarinho, Macarani C Estação Ecológica Wenceslau Guimarães and D Serra do Corcovado, Almadina, Bahia, Brazil (photographs A, B and D Iuri R. Dias, C Rafael O. Abreu).

Recordings from 1995 and 1997 were made with a SONY WM-D6 Digital Audio Track (DAT) with a directional SONY microphone. For the recordings from 2014 and 2015 a Sennheiser ME45 microphone with a K6 power module connected to a Tascam DR1 digital recorder was used. All recordings were made from a distance of about 40 $\mathrm{cm}$ from the frogs. Calls were recorded at a resolution of 16 bit and $48 \mathrm{kHz}$ sampling rate. Waveform and spectrogram were made using Raven Pro 1.4 and analyzed with a Fast Fourier Transformation of 256 points, 50\% overlap for an entire call and Window Hamming. For all other configurations the "default" settings of Raven were used. Terminology follows Littlejohn (2001). Voucher specimens are deposited at the Museu de Zoologia da Universidade Estadual de Santa Cruz (MZUESC), under catalog numbers 
Table I. Distribution records of Eleutherodactylus bilineatus based on literature review, museum data (MZUESC) and field works.

\begin{tabular}{|c|c|c|c|c|c|}
\hline Municipality & Localities & Latitude & Longitude & Reference & Voucher analyzed \\
\hline Almadina & Serra do Corcovado & -14.7011 & -39.6625 & Dias et al. 2014b & MZUESC 17015 \\
\hline Amargosa & Serra do Timbó & -13.0365 & -39.6325 & Marciano-Jr et al. 2014 & $\begin{array}{c}\text { MZUESC } \\
17026-17036\end{array}$ \\
\hline Arataca & Serra das Lontras & -15.1624 & -39.3437 & This study & MZUESC 17025 \\
\hline Barro Preto & Serra da Pedra Lascada & -14.7723 & -39.5408 & This study & MZUESC 17016 \\
\hline Boa Nova & - & -14.3591 & -40.2383 & Berneck et al. & - \\
\hline Cairu & Fazenda Subaúma & -13.5067 & -38.9812 & Silvano and Pimenta 2003 & - \\
\hline Camacan & RPPN Serra Bonita & -15.4413 & -39.5189 & Dias et al. 2014a & $\begin{array}{c}\text { MZUESC 8616-17; } \\
8359 ; 8457 \\
\end{array}$ \\
\hline Canavieiras & - & -15.6750 & -38.9469 & Berneck et al. 2013 & - \\
\hline & Fazenda Vista Bela & & -40.0586 & Silvano and & - \\
\hline Igrapiúna & $\begin{array}{l}\text { Reserva Ecológica da } \\
\text { Michelin }\end{array}$ & -13.8585 & -39.1728 & Camurugi et al. 2010 & $\begin{array}{c}\text { MZUESC } \\
14222-14223\end{array}$ \\
\hline Ilhéus & CEPLAC/UESC & -14.7867 & -39.2249 & Bokermann 1975 & MUESC 8110 \\
\hline Jequié & - & -13.9654 & -40.0002 & This study & MZUESC 7961 \\
\hline Jussari & $\begin{array}{l}\text { N Serra do } \\
\text { loso }\end{array}$ & -15.1675 & -39.5444 & Pimenta and Silvano 2002 & - \\
\hline Macarani & $\begin{array}{l}\text { RPPN Mata do Pas- } \\
\text { sarinho }\end{array}$ & -15.7907 & -40.5192 & This study & $\begin{array}{c}\text { MZUESC } \\
16979-16991\end{array}$ \\
\hline Nilo Peçanha & Fazenda São João & -13.6585 & -39.1884 & Pimenta and Silvano 2002 & - \\
\hline Itarantim & Serra do Mandim & -15.6295 & -39.9803 & This study & $\begin{array}{c}\text { MZUESC 15095- } \\
15097,15855- \\
15856\end{array}$ \\
\hline $\begin{array}{l}\text { Santa Tere- } \\
\text { sinha }\end{array}$ & Serra da Jibóia & -12.7283 & -39.5694 & Juncá 2006 & $\begin{array}{c}\text { MZUESC } \\
\text { 17007-17014; } \\
\text { MZFS 309, 600 }\end{array}$ \\
\hline & Fazenda Provisão & -14.6512 & -39.2232 & This study & MZUESC 14444 \\
\hline Valença & RPPN Água Branca & -13.3791 & -39.0916 & This study & MZUESC 13658 \\
\hline $\begin{array}{l}\text { Wenceslau } \\
\text { Guimaráes }\end{array}$ & $\begin{array}{l}\text { Estação Ecológica de } \\
\text { Wenceslau Guimarães }\end{array}$ & -13.6285 & -39.6264 & Pimenta and Silvano 2002 & $\begin{array}{c}\text { MZUESC } \\
17017-17019\end{array}$ \\
\hline
\end{tabular}

MZUESC 17007-17008 from Serra da Jibóia and MZUESC 16979-16991 (one of these specimens was recorded while specimens were kept in a plastic bag in Macarani) and Museu de Zoologia da Universidade Estadual de Feira de Santana (MZFS), under catalog number MZFS 309 and 600 from Serra da Jibóia.

\section{Results and discussion}

During field expeditions, 151 individuals of Eleutherodactylus bilineatus were registered in all locations sampled, except in PARNA do Alto do Cariri, municipality of Guaratinga, where the species was not found. The areas located more northwards revealed the largest abundances of this species: Serra do Timbó $(\mathrm{n}=44)$, Serra da Jibóia $(\mathrm{n}=43)$ and 


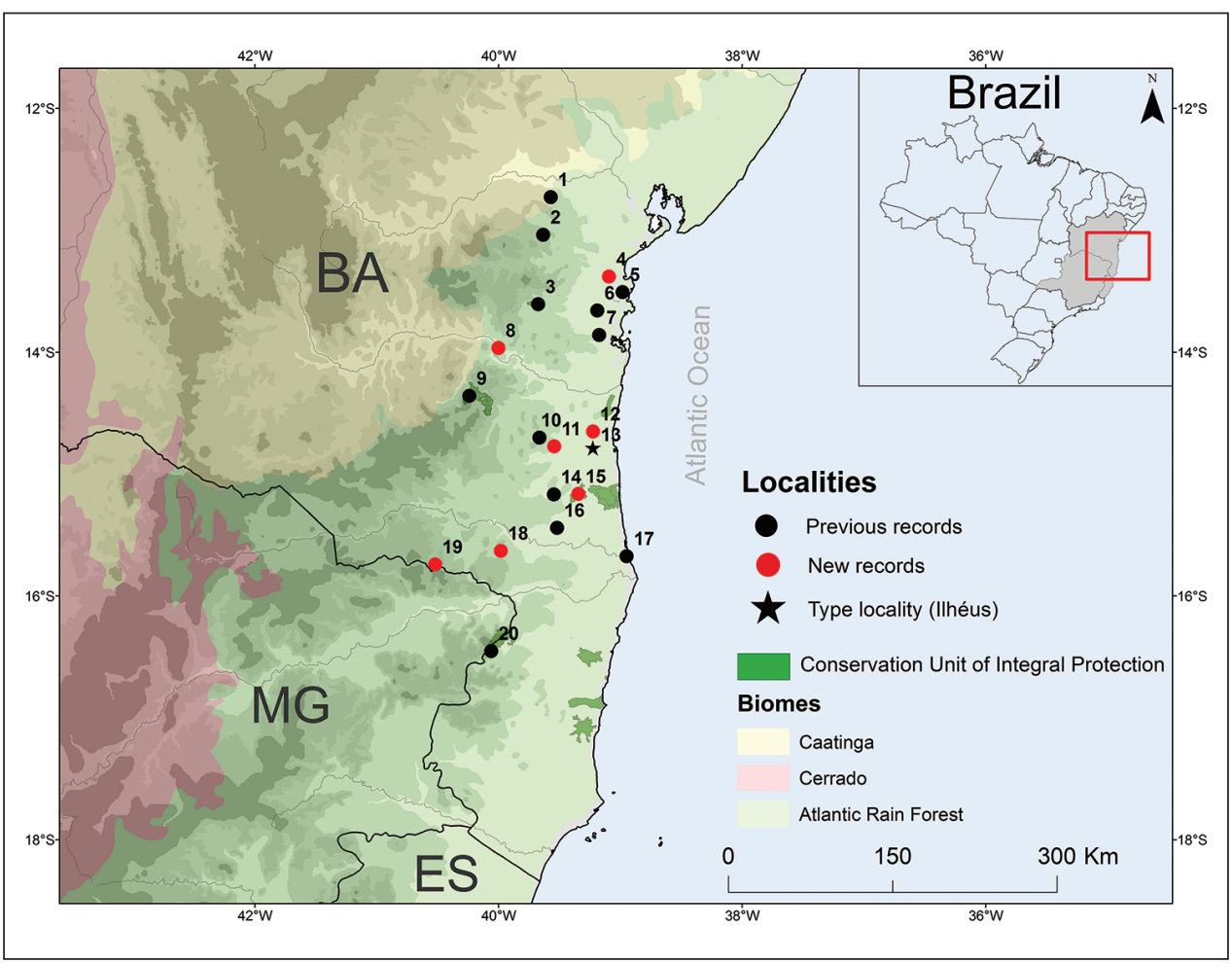

Figure 2. Distribution map of known localities for Eleutherodactylus bilineatus. Key: black star = type locality; red circle $=$ new records; black circles $=$ literature records. Municipalities $=\mathbf{I}$ Santa Teresinha 2 Amargosa 3 Wenceslau Guimarães 4 Valença 5 Cairu 6 Nilo Peçanha 7 Igrapiúna 8 Jequié 9 Boa Nova 10 Almadina II Barro Preto 12 Uruçuca 13 Ilhéus (Type Locality) I4 Jussari 15 Arataca, 16 Camacan 17 Canavieiras 18 Itarantim 19 Macarani and 20 Guaratinga. BA = state of Bahia; MG = state of Minas Gerais and ES = state of Espírito Santo. More details of the records are present in Table 1.

Wenceslau Guimarães $(\mathrm{n}=35)$. In Macarani, located in the southeastern portion of Bahia we also encountered a high abundance with 24 individuals. At the other localities, records were limited to only one or two individuals.

Four new distribution records of specimens deposited in the Museum of Zoology of Universidade Estadual de Santa Cruz were found. Thus, the distribution map for the species is updated (Table 1, Figure 2), including seven new records and expanding the known distribution of Eleutherodactylus bilineatus in $110 \mathrm{~km}$ eastward of the RPPN Serra Bonita, in the municipality of Camacan (Dias et al. 2014a) to the RPPN Mata do Passarinho in the municipality of Macarani, representing the most inland record for the species. Thus, Eleutherodactylus bilineatus is distributed in rainforest areas, semideciduous seasonal Forest, and also in shaded cocoa plantations (locally known as "cabrucas"), from the Paraguaçu river to the surroundings of the Jequitinhonha river with its most inland records coming from Boa Nova and Macarani. The species can be found from sea level up to 900 meters. 


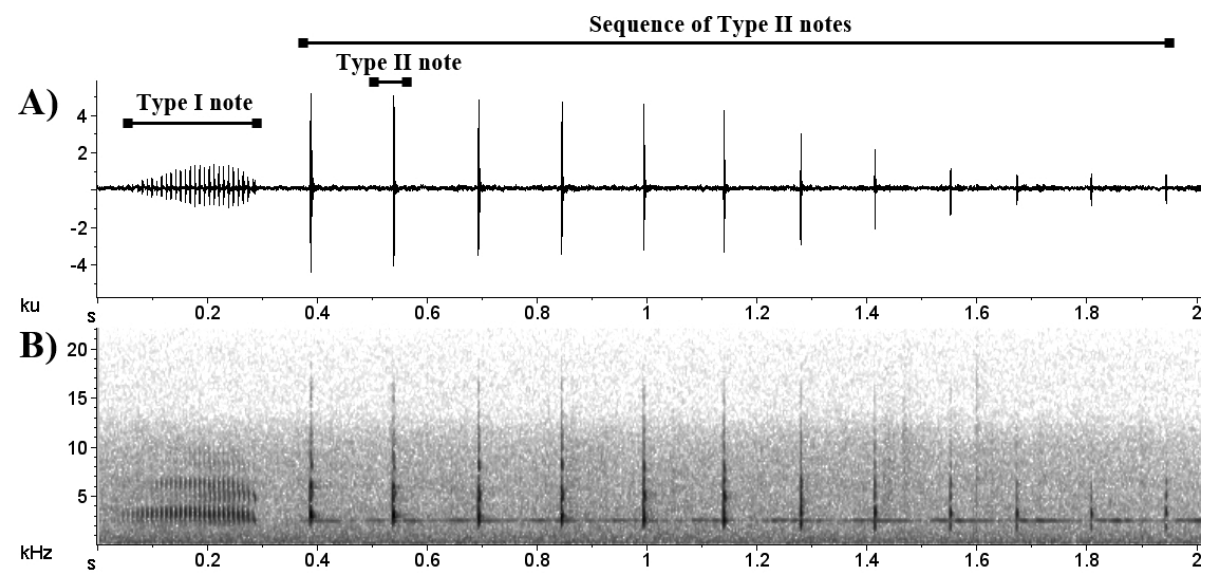

Figure 3. Advertisement call of Eleutherodactylus bilineatus (MZFS 600). (A) Waveform and (B) audiospectrogram. Recorded on April 21, 1997 at 20h 50min. Air temperature during recording $20^{\circ} \mathrm{C}$.

Males began calling in the early evening, at places with dense leaf litter on the forest floor, near fallen trunks and tabular roots. During our observations (March 03, 2015) several individuals $(\mathrm{n}=5-10)$ were calling together at the sites of recording, and calling activity decreased after 8:00 pm. In the RPPN Mata do Passarinho the advertisement call was heard sporadically, especially during the early evening. However, after one night of heavy rain, several males could be heard calling between 15:00-16:00 h.

The advertisement call (Figure 3) of Eleutherodactylus bilineatus had a total duration of $0.529-4.241 \mathrm{~s}(2.06 \pm 0.67, \mathrm{n}=54)$ and dominant frequency of $1.72-3.45$ $\mathrm{kHz}(2.90 \pm 473, \mathrm{n}=54)$. Two different notes composed the advertisement call; a longer one, here called "Type I" and a shorter one called "Type II". The two note types are emitted in sequence but in $-15 \%(n=8)$ of the analyzed calls $(n=54)$ "Type I" was not issued. "Type I" note (or introductory note) had a total duration of $0.124-0.695 \mathrm{~s}$ $(0.321 \pm 0.133, \mathrm{n}=46)$ and consisted of $17-103$ pulses $(41 \pm 19)$. The pulse duration of "Type I" note was $0.0035 \pm 0.0007 \mathrm{~s}(0.001-0.006 ; \mathrm{n}=258)$ with interval between pulses of $0.005 \pm 0.0008 s(0.003-0.007 ; n=248)$. The dominant frequency of "Type I" note was between $2.41-3.27 \mathrm{kHz}(3.07 \pm 210)$.

Intervals of $0.07-0.116 \mathrm{~s}(0.09 \pm 0.01, \mathrm{n}=45)$ separated the two different note types. "Type II" was emitted in a sequence of $6-31$ notes $(13.98 \pm 4.89, \mathrm{n}=54)$ with duration of $0.001-0.02 s(0.004 \pm 0.003, \mathrm{n}=664)$ each with an interval between notes ranging from 0.07 to $0.21 \mathrm{~s}(0.13 \pm 0.015, \mathrm{n}=660)$. The dominant frequency of "Type II" notes was $1.72-3.96 \mathrm{kHz}(2.91 \pm 423)$ and oscillated between the first $(\mathrm{n}=9)$ and second $(\mathrm{n}=31)$ harmonic. Four harmonic bands could be discerned, with peaks between $1.57-2.07 \mathrm{kHz}$; the second peak between $2.76-3.45 \mathrm{kHz}$; the third peak between $4.24-5.02 \mathrm{kHz}$ and the fourth peak between $5.75-614 \mathrm{kHz}$.

The recordings from Macarani lasted longer and had a higher number of "Type II" notes (more than twice the average) than the recordings from Serra da Jibóia. In Macarani individuals were recorded inside a plastic bag, where they had been placed 
Table 2. Acoustic parameters of advertisement call of Noblella and Barycholos, genera more closely related with Eleutherodactylus bilineatus according to Canedo and Haddad (2012). Temporal variables in miliseconds (ms).

\begin{tabular}{l|c|c|c|c}
\hline & Barycholos ternetzi & Noblella carrascoicola & Noblella lochites & Noblella personina \\
\hline Number of Note & 1 & $5-8(6.0 \pm 1.2)$ & $6-8$ & $5-11$ \\
\hline Duration of Call & $30-79$ & $\begin{array}{c}254-436 \\
(332.3 \pm 62.6)\end{array}$ & $\begin{array}{c}369-537 \\
(428.53 \pm 53.60)\end{array}$ & $\begin{array}{c}570-1524 \\
(1052 \pm 307)\end{array}$ \\
\hline Duration of each note & - & $12-20$ & $6-17$ \\
$(11.50 \pm 2.90)$ & $\begin{array}{c}13-20 \\
(16 \pm 2)\end{array}$ \\
\hline Interval between notes & - & - & $\begin{array}{c}51-95 \\
(60.39 \pm 5.77)\end{array}$ & $\begin{array}{c}103-166 \\
(128 \pm 14)\end{array}$ \\
\hline Pulses per call & $4-12$ & - & - & - \\
\hline Dominant Frequency & $\begin{array}{c}(7.16 \pm 1.45-4.31 \\
(3.77 \pm 1.75)\end{array}$ & $3.3-4.0$ & $\begin{array}{c}3.51-3.93 \\
(3.73 \pm 0.11)\end{array}$ & $\begin{array}{c}3.91-4.39 \\
(4.10 \pm 0.13)\end{array}$ \\
\hline Reference & Lemes et al. 2012 & Köhler 2000 & $\begin{array}{c}\text { Batalla and Brito } \\
2014^{\dagger}\end{array}$ & \begin{tabular}{c} 
Harvey et al. 2013 \\
\hline
\end{tabular}
\end{tabular}

${ }^{\dagger}$ They considered that the call was formed by pulses.

together with other individuals of Eleutherodactylus bilineatus, as well as individuals from other species as Ischnocnema verrucosa and Dendrophryniscus proboscideus. The observed difference in acoustic parameters could be associated to some kind of social context (e.g. agonistic interactions) and should be further investigated.

The uncertain taxonomic position of this species hampers the comparison of the acoustic parameters with other closely related species. Following Canedo and Haddad (2012) this species would be more closely related with Noblella and Barycholos. From the 14 known species of these two genera four have had their advertisement calls described (see Table 2): Barycholos ternetzi (Lemes et al. 2012); Noblella carrascoicola (Köhler 2000), N. lochites (Batallas and Brito 2014) and N. personina (Harvey et al. 2013). The advertisement call of $B$. ternetz $i$ is a trill consisting of a short multi-pulsed note (30-79 ms) with 4 to 12 pulses per call. The calls of the species belonging to the genus Noblella show between 5 and 11 notes lasting between 254-1524 ms with a dominant frequency varying between $3.30-4.39 \mathrm{kHz}$. The structure of the known calls of the genus Noblella is more similar with the "Type II" call of Eleutherodactylus bilineatus, with a call composed by series of notes with similar temporal and spectral acoustic parameters. However, none of the compared species showed two types of notes in the same call as in E. bilineatus.

The relationships within this clade (E. bilineatus, Noblella, Barycholos) require a more extensive approach, including morphological information in order to determine the taxonomic position of E. bilineatus, as well as the inclusion of molecular data into the phylogenetic analyses of other species of Holoadeninae (Canedo and Haddad 2012). As highlighted by Padial et al. (2014) the relationships within this subfamily provide insights on the possible connection between the Andes (Noblella), the Atlantic Forest of Northeastern Brazil (E. bilineatus), and the Cerrado (Barycholos ternetzi) deserving a more accurate exploration of the biogeography in the future. 


\section{Acknowledgments}

We are grateful to the Fundação Biodiversitas and manager Alexandre Enout of RPPN Mata do Passarinho and GAMBA (Grupo Ambientalista da Bahia) for allowing us access to research areas (Macarani and Serra da Jibóia, respectively) under their care and for logistical assistance. We thank the Fundação Grupo Boticario de Proteção à Natureza (0991_20132), FAPESB (5154/2014), PROTAX-CNPq (440615/2015-1) and Rede Baiana de Pesquisa sobre Anfíbios (RBPA) - "Padróes e processos da diversidade de anfíbios na Bahia: influência das mudanças climáticas e propostas de conservação", supported by FAPESB and the "Secretaria do Meio Ambiente da Bahia" (PAM0005/2014) for funding the project. Scholarships were provided by the Conselho Nacional de Desenvolvimento Científico e Tecnológico (CNPq-Project: 404417/2015-9, Process: 150372/2016-7) to IRD and by the Fundação de Amparo à Pesquisa do Estado da Bahia (BOL0853/2012) to CVMM.

\section{References}

Batallas RD, Brito MJ (2014) Description of the advertisement call of Noblella lochites (Anura: Craugastoridae)/Descripción del llamado de advertencia de Noblella lochites (Anura: Craugastoridae). Avances en Ciencias e Ingenierías 6(1): B6-B8.

Berneck BV, Targino M, Garcia PCA (2013) Rediscovery and re-description of Ischnocnema nigriventris (Lutz, 1925) (Anura: Terrarana: Brachycephalidae). Zootaxa 694(2): 131-142. https://doi.org/10.11646/zootaxa.3694.2.2

Bokermann WCA (1975 "1974") Três espécies novas de Eleutherodactylus do sudeste da Bahia, Brasil (Anura, Leptodactylidae). Revista Brasileira de Biologia 34: 11-18.

Canedo C, Haddad CFB (2012) Phylogenetic relationships within anuran clade Terrarana, with emphasis on the placement of Brazilian Atlantic rainforest frog genus Ischnocnema (Anura: Brachycephalidae). Molecular Phylogenetics and Evolution 65(2): 610-620. https://doi. org/10.1016/j.ympev.2012.07.016

Camurugi F, Lima TM, Mercês EDA, Juncá FA (2010) Anurans of the Reserva Ecológica da Michelin, municipality of Igrapiúna, state of Bahia, Brazil. Biota Neotropica 10(2): 305-312. https://doi.org/10.1590/S1676-06032010000200032

Dias IR, Medeiros TT, Vila Nova MF, Solé M (2014a) Amphibians of Serra Bonita, southern Bahia: a new hotpoint within Brazil's Atlantic Forest hotspot. Zookeys 449: 105-130. https://doi.org/10.3897/zookeys.449.7494

Dias IR, Mira-Mendes CV, Solé M (2014b) Rapid inventory of herpetofauna at the APA (Environmental Protection Area) of the Lagoa Encantada and Rio Almada, Southern Bahia, Brazil. Herpetology Notes 7: 627-637.

Frost DR (2016) Amphibian Species of the World: an Online Reference. Version 6.0. American Museum of Natural History, New York, USA. Electronic Database. research.amnh.org/vz/ herpetology/amphibia/ [Accessed: 18 January 2017] 
Harvey MB, Almendáriz A, Brito MJ, Batallas RD (2013) A new species of Noblella (Anura: Craugastoridae) from the Amazonian Slopes of the Ecuadorian Andes with comments on Noblella lochites (Lynch). Zootaxa 3635(1): 1-14. https://doi.org/10.11646/zootaxa.3635.1.1 Juncá FA, Pimenta B (2004) Eleutherodactylus bilineatus. The IUCN Red List of Threatened Species. https://doi.org/10.2305/IUCN.UK.2004.RLTS.T56462A11468784.en [16 January 2017]

Juncá FA (2006) Diversidade e uso de hábitat por anfíbios anuros em duas localidades de Mata Atlântica, no norte do Estado da Bahia. Biota Neotropica 6(2): 1-8. https://doi. org/10.1590/S1676-06032006000200018

Köhler J (2000) A new species of Phyllonastes Heyer from the Chapare region of Bolivia, with notes on Phyllonastes carrascoicola. Spixiana 23(1): 47-53.

Lemes P, Tessarolo G, Morais AR, Bastos RP (2012) Acoustic repertoire of Barycholos ternetzi (Anura: Strabomantidae) in Central Brazil. South American Journal of Herpetology 7(2): 157-164. https://doi.org/10.2994/057.007.0205

Littlejohn MJ (2001) Patterns of differentiation in temporal properties of acoustic signals of anurans. In: Ryan MJ (Ed.) Anuran Communication. Smithsonian Institution Press, Washington, 102-120.

Marciano-Jr E, Camardelli M, Matos M (2013) Ischnocnema bilineata (Reproduction). Herpetological Review 44(1): 122-123.

Padial JM, Grant T, Frost DR (2014) Molecular systematics of Terraranas (Anura: Brachycephaloidea) with an assessment of the effects of alignment and optimality criteria. Zootaxa 3825: 1-132. https://doi.org/10.11646/zootaxa.3825.1.1

Pimenta BVS, Silvano DL (2002) Eleutherodactylus bilineatus. Herpetological Review 33(2): 144. Silvano DL, Pimenta BVS (2003) Diversidade de anfíbios na Mata Atlântica do Sul da Bahia. In: Prado PI, Landau EC, Moura RT, Pinto LPS, Fonseca GAB, Alger K (Eds) Corredor de Biodiversidade na Mata Atlântica do Sul da Bahia. IESB/CI/CABS/UFMG/UNICAMP, $1-22$. 